\title{
Homocysteine and folate levels as indicators of cerebrovascular accident
}

VO Osunkalu'

AT Onajole ${ }^{2}$

KA Odeyemi

BA Ogunnowo 2

AO Sekoni ${ }^{2}$

GA Ayoola ${ }^{3}$

A Adediran'

OR Akinde ${ }^{4}$

AT Adeyemo'

'Department of Haematology and Blood Transfusion, ${ }^{2}$ Department of Community Health, ${ }^{3}$ Department of Pharmacognosy, ${ }^{4}$ Department of Morbid Anatomy, College of Medicine, University of Lagos, Nigeria
Correspondence: VO Osunkalu

Plot 30, Jibowu Estate, U-Turn Bus-Stop, Abule-Egba, Lagos, Nigeria

Tel +234802 32I 48I6

Email doctorvincent4real@yahoo.com
This article was published in the following Dove Press journal:

Journal of Blood Medicine

10 July 2010

Number of times this article has been viewed

Background: Homocysteinemia has been established as a risk factor for cardiovascular disorders by the American Heart Association. ${ }^{1}$ Cerebrovascular accident (stroke) is presently ranked as one of the leading causes of morbidity and mortality worldwide. The aim of this study was to determine homocysteine and folate levels and some basic hematologic parameters in patients who sustain a cerebrovascular accident and those who do not.

Methodology: In total, 100 participants were recruited, comprising 40 clinically diagnosed stroke (hemorrhagic or thromboembolic) patients and 60 healthy control subjects. Plasma homocysteine and folate levels were measured. Anticoagulated whole blood samples were evaluated for hemoglobin concentration $(\mathrm{Hb})$, packed cell volume (PCV), white blood cell (WBC) count, and mean cell volume (MCV).

Results: The mean age of stroke patients was $62 \pm 12$ years and that of controls was $55 \pm 18$ years $(P=0.1756)$. Mean plasma homocysteine levels for stroke patients and controls were $17.7 \pm 4.4 \mu \mathrm{mol} / \mathrm{L}$ and $9.5 \pm 2.4 \mu \mathrm{mol} / \mathrm{L}$, respectively $(P=0.0000)$ and mean plasma folate levels for the groups were $6.5 \pm 2.9 \mu \mathrm{g} / \mathrm{dL}$ and $4.0 \pm 2.4 \mu \mathrm{g} / \mathrm{dL}(P=0.0407)$. The MCV for stroke patients was significantly higher than that for controls ( $85 \mathrm{fl}$ versus $82 \mathrm{fl}, P=0.04$ ). Mean homocysteine levels correlated inversely with $\mathrm{Hb}$ and PCV $(r=-0.08$ and $r=-0.122$, respectively) and weakly with $\mathrm{WBC}(P=0.125)$.

Conclusion: Homocysteinemia is a major predictor of cerebrovascular accident in the black Nigerian population.

Keywords: homocysteinemia, folate, cerebrovascular accident

\section{Introduction}

Homocysteine is an amino acid in the blood. Epidemiologic studies have shown that elevated plasma homocysteine is related to a higher risk of coronary heart disease, stroke, and peripheral vascular disease. ${ }^{1}$ Other evidence suggests that homocysteine may have an effect on atherosclerosis by damaging the inner lining of arteries and promoting blood clots. ${ }^{2}$ Plasma homocysteine levels are strongly influenced by diet, as well as by genetic factors. The dietary components with the greatest effects are folic acid and vitamin B6 and B12. Folic acid and other B vitamins help break down homocysteine in the body. ${ }^{3}$ Several studies have found that higher blood levels of $\mathrm{B}$ vitamins are related, at least in part, to lower concentrations of homocysteine. Other recent evidence shows that low blood levels of folic acid are linked to a higher risk of fatal coronary heart disease and stroke. However, many studies still give conflicting reports of the association between plasma folate levels and increasing plasma homocysteine levels. Most of the relevant published data are for Caucasians, and there is a 
paucity of data for black populations, especially in Nigeria where nutritional deficiencies have been well documented in a large proportion of the population. ${ }^{4,5}$

With an upsurge in reported cases of cardiovascular disease and related mortality, it has become important to determine plasma homocysteine levels as a possible predictive index of the risk of developing cardiovascular disorders. $^{4}$

Homocysteine testing may be useful in checking the overall risk of heart disease for people with a strong personal or family history of heart disease but who do not have other risk factors that can be controlled, such as smoking or high blood pressure. Homocysteine testing may also be useful for people who have early heart disease but no known risk factors and for people who have had unexplained deep vein thrombosis or stroke. ${ }^{1}$

\section{Materials and methods Study location}

The study was carried out at the Lagos University Teaching Hospital, Idi-Araba, and at the Lagos State University College of Medicine, Ikeja, both located in Lagos State, South West Nigeria. These centers are the peak tertiary referral health institutions in the state. The entire patient cohort seen with high blood pressure within a two-month period of data collection and who had had a cerebrovascular accident (CVA) were selected for this study.

\section{Study population and inclusion criteria}

There were 100 participants in this study, comprising 40 clinically diagnosed stroke patients (all hospital admissions) recruited over a period of two months and presenting primarily with blood pressure readings above $140 / 90 \mathrm{mmHg}$, hemiparesis, and loss of consciousness, and with no other documented history of chronic systemic disorders. Sixty clinically stable, age- and gender-matched control subjects were selected randomly from people coming to the hospital outpatient clinic for voluntary routine blood pressure check-up and urinalysis as a control group. Ethical approval for the study was obtained from the Ethical Committee of the Lagos University Teaching Hospital, and verbal consent was obtained from all participants in the study.

\section{Sample collection and processing}

Two venous nonfasting $4.5 \mathrm{~mL}$ blood samples were drawn from each subject, put into anticoagulant tubes containing sodium ethylenediaminetetraacetic acid (EDTA) and heparin, and immediately placed in an ice pack cooler.
Plasma obtained after centrifugation at $3000 \mathrm{rpm}$ was stored. A homocysteine assay was done, using an enzyme-linked immunosorbent assay (ELISA, Diazyme Laboratories, La Jolla, CA). Folate levels were measured using high performance liquid chromatography (HPLC). Hematologic parameters, including hemoglobin $(\mathrm{Hb})$, packed cell volume (PCV), white blood cell (WBC) count, and mean cell volume (MCV) were obtained from the sodium EDTA anticoagulated blood sample using the automated Coulter cell counter (Advia 60, France). ${ }^{6}$

Homocysteine values were read off at a wavelength of $380 \mathrm{~nm}$ (ultraviolet), and the actual concentration of plasma homocysteine was extrapolated from the standard curve. Folate values were read off the measured areas of the chromatograph, and actual concentration was estimated on the calibration curve obtained with the standards.

\section{Statistical analysis}

Data obtained were analyzed using the SPSS version 11 (SPSS Inc., Chicago, IL). Quantitative variables were expressed as means \pm standard deviation. Relationships were subjected to the student t-test and associations verified by Chi-square and Pearson correlation coefficient.

\section{Results}

The mean age of controls compared well with the mean age of the stroke patients (62 \pm 12 years and $58 \pm 18$ years, respectively, $P=0.1756$ ), as shown in Table 1 . The mean value of homocysteine was $17.7 \pm 4.4 \mu \mathrm{mol} / \mathrm{L}$ in the stroke patients, and this was significantly higher than for controls $(9.5 \pm 2.4 \mu \mathrm{mol} / \mathrm{L}, P=0.0001)$. The mean value of serum folate was higher among the stroke patients than in controls $(6.5 \pm 2.9$ and $4.0 \pm 2.4$, respectively, $P=0.0407)$.

There was no significant difference in the mean values of $\mathrm{Hb}, \mathrm{PCV}$, and $\mathrm{WBC}$ count for stroke patients and controls ( $P=0.5144, P=0.1784$, and $P=0.3356$, respectively). Mean values for homocysteine did not correlate well with $\mathrm{Hb}$, $\mathrm{PCV}$, or WBC count between stroke patients and controls ( $r=-0.08,-0.122$, and 0.125 , respectively). However, the

Table I Demographic characteristics of study participants

\begin{tabular}{llll}
\hline Variables & $\begin{array}{l}\text { Study group } \\
\text { F (\%) }\end{array}$ & $\begin{array}{l}\text { Control group } \\
\mathbf{F ~ ( \% ) ~}\end{array}$ & $\begin{array}{l}\boldsymbol{P} \text { value } \\
\text { (t-test) }\end{array}$ \\
\hline Males & $28(70)$ & $40(67)$ & \\
Female & $12(30)$ & $20(33)$ & \\
Total & $40(100)$ & $60(100)$ & \\
Mean age & $62 \pm 12$ years & $58 \pm 18$ years & 0.1756 \\
\hline
\end{tabular}


Table 2 Mean values $( \pm S D$ ) of measured hematological parameters, plasma homocysteine and folate in both control and study groups

\begin{tabular}{llll}
\hline $\begin{array}{l}\text { Measured } \\
\text { parameters }\end{array}$ & $\begin{array}{l}\text { Study } \\
\text { group }\end{array}$ & $\begin{array}{l}\text { Control } \\
\text { group }\end{array}$ & $\begin{array}{l}\text { P value } \\
\text { (t-test) }\end{array}$ \\
\hline $\mathrm{Hb}(\mathrm{g} / \mathrm{dL})$ & $11.6 \pm 2.3$ & $12.1 \pm 1.6$ & $0.5 \mathrm{I} 44$ \\
$\mathrm{PCV}(\%)$ & $34.6 \pm 7.1$ & $36.6 \pm 4.8$ & 0.1784 \\
$\mathrm{WBC}\left(\right.$ cells $\left.\times 10^{9} / \mathrm{L}\right)$ & $5893 \pm 263.5$ & $5142 \pm 510$ & 0.3356 \\
$\mathrm{MCV}(\mathrm{fl})$ & $85 \pm 4.8$ & $82 \pm 2.9$ & 0.04 \\
Homocysteine $(\mu \mathrm{mol} / \mathrm{L})$ & $17.7 \pm 4.4$ & $9.5 \pm 2.4$ & 0.0000 \\
Folate $(\mu \mathrm{g} / \mathrm{L})$ & $6.5 \pm 2.9$ & $4.0 \pm 2.4$ & 0.0407 \\
\hline
\end{tabular}

Abbreviations: $\mathrm{Hb}$, hemoglobin; $\mathrm{PCV}$, packed cell volume; $\mathrm{SD}$, standard deviation WBC, white blood cell count; MCV, mean cell volume.

MCV for stroke patients ( $85 \mathrm{fl}$ ) was higher than for controls ( $82 \mathrm{fl}, P=0.04)$.

High mean plasma homocysteine levels $(>10 \mu \mathrm{mol} / \mathrm{L})$ correlated well with the occurrence of stroke, with $88 \%$ of stroke patients having levels above $10 \mu \mathrm{mol} / \mathrm{L}(P=0.00001)$. Mean folate levels were higher in the stroke patients. Table 4 shows a higher association of stroke with a plasma folate level below $6 \mu \mathrm{g} / \mathrm{L}(P=0.037)$.

\section{Discussion}

Of the 40 stroke patients who participated in our study, $70 \%$ $(\mathrm{n}=28)$ were males and $30 \%(\mathrm{n}=12)$ were females. A previous study by Andrew et $\mathrm{al}^{2}$ showed no significant difference in gender prevalence of homocysteinemia. Mean homocysteine levels for both male and female participants in this study were $18.2 \mu \mathrm{mol} / \mathrm{L}$ and $17.1 \mu \mathrm{mol} / \mathrm{L}$, respectively $(P=0.217)$. The majority of our stroke patients were elderly (mean age $62 \pm 12$ years), corresponding well with the controls (mean age $58 \pm 18$ years, $P=0.1756$ ). Mean values for plasma homocysteine in the stroke patients $(17.7 \pm 4.4 \mu \mathrm{mol} / \mathrm{L})$ were significantly higher than that in controls $(9.5 \pm 2.4 \mu \mathrm{mol} / \mathrm{L})$. This finding is consistent with results obtained by Nura et $\mathrm{al}^{3}$ in Maiduguri, Northern Nigeria, who recorded a mean plasma homocysteine level of $20.8 \mu \mathrm{mol} / \mathrm{L}$ and $13.1 \mu \mathrm{mol} / \mathrm{L}$ for stroke patients and controls, respectively.

The literature is replete with information on the association between high plasma homocysteine levels and stroke incidence. In a study of stroke in the elderly, Andrew et $\mathrm{al}^{2}$ concluded that nonfasting hyperhomocysteinemia is an independent risk factor for the incidence of stroke in this age group. Interestingly, their study failed to find this association in Finnish men, an indication of possible geographical variations in the incidence of hyperhomocysteinemia. In a study of adults with stroke in Gombe, Northern Nigeria, Glew et $\mathrm{al}^{4}$ showed no significant difference in plasma homocysteine levels of stroke patients and controls, although $85 \%$ of the stroke patients had plasma homocysteine levels above $10 \mu \mathrm{mol} / \mathrm{L} .{ }^{4,5}$ Homocysteine induces oxidant damage of vascular endothelium, and thus increases the incidence of atherosclerosis and disturbance of normal hemostasis. Our study calculated an odds ratio of 14 as shown in Table 3, an indication that a homocysteine level above $10 \mu \mathrm{mol} / \mathrm{L}$ is a significant risk factor for stroke $(P=0.0001)$. Mean plasma folate in the stroke patients was significantly higher than that in controls $(6.5 \pm 2.9 \mu \mathrm{g} / \mathrm{L}$ versus $4.0 \pm 2.4 \mu \mathrm{g} / \mathrm{L}, P=0.0407)$. This finding is at variance with other studies in which lower plasma folate levels were found. ${ }^{6-9}$ In a study of homocysteine in pregnant women, Megahad and Thahor ${ }^{9}$ reported a negative correlation between plasma folate and plasma homocysteine levels. ${ }^{9}$ However, the high level of plasma folate reported in this study may be iatrogenic, because virtually all the stroke patients were taking folate supplements. This position is further supported by the fact that the occurrence of stroke in our patients was significantly associated with plasma folate levels below $6 \mu \mathrm{g} / \mathrm{L}(P=0.037$, odds ratio 2.45). Moreover, the mean MCV of our stroke patients was significantly higher than that in the control group $(85 \pm 4.8 \mathrm{fl}$ versus $82 \pm 2.9$ $\mathrm{fl}, P=0.04)$. This implies the existence of a subtle folate deficiency prior to the occurrence of stroke in these patients. However, no significant differences were observed between the mean values of $\mathrm{Hb}, \mathrm{PCV}$, and $\mathrm{WBC}$ count in our stroke patients and controls $(0.1784$ and 0.3356 , respectively, $P=0.5144)$, and the mean values of homocysteine correlated inversely, albeit weakly, with the $\mathrm{Hb}$ and PCV of the study group ( $r=-0.08$ and -0.122 , respectively) and very weakly with the WBC of the study group ( $r=0.125)$. This finding is consistent with a previous observation by Haddad et al. ${ }^{10}$

Table 3 Relationship between high homocysteine values and occurrence of stroke*

\begin{tabular}{|c|c|c|c|c|c|}
\hline Groups & $\begin{array}{l}\text { Plasma homocysteine } \\
(>10 \mu \mathrm{mol} / \mathrm{L}) \mathrm{n}(\%)\end{array}$ & $\begin{array}{l}\text { Plasma homocysteine } \\
(<10 \mu \mathrm{mol} /) \mathrm{n}(\%)\end{array}$ & Total & Chi-square & $P$ value \\
\hline Stroke patients & $35(87.5)$ & $5(12.5)$ & 40 & & \\
\hline Controls & $20(33.3)$ & $40(66.7)$ & 60 & & \\
\hline Total & $55(100)$ & $45(100)$ & 100 & 28.45 & 0.00001 \\
\hline
\end{tabular}

Note: $*$ Odds ratio $=14$ 
Table 4 Association between high plasma folate and occurrence of stroke*

\begin{tabular}{lllll}
\hline Group & $\begin{array}{l}\text { Plasma folate } \\
(>\mathbf{6} \mu \mathbf{g} / \mathbf{L}) \mathbf{n}(\%)\end{array}$ & $\begin{array}{l}\text { Plasma folate } \\
(<\mathbf{6} \mu \mathbf{g} / \mathbf{L}) \mathbf{n}(\%)\end{array}$ & Total & Chi-square \\
\hline Stroke patients & $18(45.0)$ & $22(55.0)$ & 40 & \\
Controls & $15(25)$ & $45(75)$ & 60 & \\
Total & $32(100)$ & $68(100)$ & 100 & 4.34 \\
\hline
\end{tabular}

Note: $*$ Odds ratio $=2.45$

The low $\mathrm{Hb}$ and hematocrit values observed in both stroke patients and controls suggests the possibility of protein malnutrition, which has been correlated with hyperhomocysteinemia in other research in African populations. ${ }^{11}$

\section{Conclusion}

The results of our study indicate that folate deficiency alone might not explain high levels of homocysteine in blacks with cardiovascular disorders, and future studies evaluating protein and calorie malnutrition in this population are necessary.

\section{Disclosure}

The authors report no conflicts of interest in this work.

\section{References}

1. Toole JF, René Malinow M, Chambless LE, et al. Lowering homocysteine in patients with ischemic stroke to prevent recurrent stroke, myocardial infarction, and death. JAMA. 2004;291:565-575.

2. Andrew G, Boston MD, Irwin H, et al. Non fasting plasma total homocysteine levels and stroke incidence in elderly persons. Ann Intern Med. 1999;131:352-355.
3. Nura H, Alkali, Hillary W, Sunday A, Bwale, Amos G. Association of plasma homocysteine and ischaemic stroke in a Nigerian population. Park J Med Sci. 2006;4:405-408.

4. Glew RH, Okolie H, Crossy M, et al. Serum lipid profiles and homocysteine levels in adults with stroke or myocardial infarction in the town of Gombe in Northern Nigeria. J Health Popul Nutr. 2004;22: 341-347.

5. Glew RH, William M, Corin CA, et al. Cardiovascular disease factors and diet of Fulani pastoralists of Northern Nigeria. Am J Clin Nutr. 2001;74:730-736.

6. Karsten R, Jan M. Total homocysteine in clinical practice. Ann Clin Biochem. 2000;37:627-648.

7. Lentz SR, Sobey CG, Piegors DJ, et al. Vascular dysfunction in monkeys with diet-induced hyperhomocysteinaemia. J Clin Invest. 1996; 98:24-29.

8. Rolland PH, Friggi A, Barlaiter A, et al. Hyperhomocysteinemiainduced vascular damage in the minipig. Captopril hydrochlorothiazide combination prevents elastic alterations. Circulation. 1995;91: 1161-1174.

9. Megahad MA, Thahor IM. Folate and homocysteine level in pregnancy. Br J Biomed Sci. 2004;61:84-87.

10. Haddad EH, Bark LS, Kettering JD, Hubbard RW, Peters WR. Dietary intake and biochemical, haematologic and immune status of vegans compared with non-vegetarians. Am J Clin Nutr. 1999;80:586s-593s.

11. Ingenbleek Y. Hyperhomocysteinaemia is a biomarker of sulfur deficiency in human morbidities. Open Clin Chem J. 2009;2:49-60.
Journal of Blood Medicine

\section{Publish your work in this journal}

The Journal of Blood Medicine is an international, peer-reviewed, open access, online journal publishing laboratory, experimental and clinical aspects of all topics pertaining to blood based medicine including but not limited to: Transfusion Medicine; Blood collection, Donor issues, Transmittable diseases, and Blood banking logistics; Immunohematology; Artificial and alternative blood based therapeutics; Hematology; Biotechnology/nanotechnology of blood related medicine; Legal aspects of blood medicine; Historical perspectives. The manuscript management system is completely online and includes a very quick and fair peer-review system. Visit http://www.dovepress.com/ testimonials.php to read real quotes from published authors. 